\title{
Regional Environmental Systems as a Driver of Innovative Economy in Ukraine
}

\author{
By Iuliia Gernego ${ }^{1}$, Liudmyla Petrenko ${ }^{2}$, Mykhailo Dyba ${ }^{3}$, Serhii Onikienko ${ }^{4}$
}

\begin{abstract}
Nowadays, the concept of innovative development is a generally accepted approach to promoting social and economic development paradigm both at global and national level. However, the rapid changes in external and internal conditions in relation to science and innovation caused the need to integrate innovative priorities with environmental imperatives to support sustainable development of modern society. Thereby, the above-mentioned tendencies are also highly widespread at local (regional) level, because both innovation and environmental practices play an essential role for social development, economic growth, improved productivity and competitiveness, and improved quality of life. Thereby, research problem lays upon the regional environmental systems and their influence at innovative development in Ukraine. The paper aims to provide scientific support on environmental systems development and their connection with innovative development indicators at the regional level. The research methodology is based on official statistical data on Ukrainian economy innovativeness analysis during the last ten years. The environmental component is analyzed at the regional level that allowed us to rank Ukrainian regions in accordance with the level of their environmental responsibility, propose a measure of transformation to their strategies. As the result, the groups of regional environmental strategies were defined in accordance with criteria of their effectiveness and need of transformation. Thus, the research highlights the special status of environmental economy, based on its specific characteristics and influences at innovative development, including network effects, the ability to convert environmental and innovative benefits into significant social effects, hybrid and multiplicative.
\end{abstract}

Keywords: innovative development, financial support, sustainable development, environmental economy

\section{Introduction}

\subsection{Research question}

Recently, there has been renewed interest in social and economic process intensification due to the local focus of innovative and environmental activity. The rapid trends of global economy evolution show the need to implement environmental strategies along with innovative ones within a system of sustainable environmental development. There is an urgent problem of rational use of natural resources and environmental protection, as well as the need for a systematic, comprehensive environmental and

\footnotetext{
$\mid{ }^{1}$ Associate Professor of Corporate Finance and Controlling Department, Kyiv National Economic University named after V. Hetman, Ukraine

${ }^{2}$ Associate Professor of Department of Business Economics and Entrepreneurship, Kyiv National Economic University named after V. Hetman, Ukraine

${ }^{3}$ Professor of Corporate Finance and Controlling Department, Kyiv National Economic University named after V. Hetman, Ukraine

${ }^{4}$ Professor of Corporate Finance and Controlling Department, Kyiv National Economic University named after V. Hetman, Ukraine
} 
economic approach to solving the above-mentioned problems at the regional level. These tendencies are also concerned within a particular concept of environmental responsible economics or green economics (Ministry of Economy of Ukraine 2020).

Thus, competitive economy requires high-tech development through regional innovation networks, clusters, regional research and information systems. However, despite the hightech and information priorities of the innovative economy, the issues of interaction between environment and society, environmental protection remain urgent. The problems of preservation and restoration of environmental systems, their diversity and the ability to self-regulation are concerned as one of the priority conditions for sustainable economic development; development of a number of measures to prevent negative environmental consequences as a result of economic activity; calculation of environmental losses and risks due to the projects implementation; determination of the ecological price of economic goods taking into account the product life cycle; differentiation of the investment climate. In particular, in light of recent global tendencies, it is becoming extremely difficult to ignore the existence of specific environmental and innovative policies on the level of particular regions and cities. The formation of the concept of regional systems as a theoretical basis for the development and effective implementation of a strategy to increase national and international competitiveness of the region becomes especially important. The sustainable innovative activity is transforming the region into focal points of the global environmental network.

In developed countries it has become traditional to take into account the priority aspects of the production process interaction with the processes of natural resources reproduction. This leads to the development and dissemination of innovative methods, technologies and principles of high-quality and sustainable production.

In the context of innovative development of Ukrainian economy, along with the need to overcome the economic crisis and strengthen economic growth trends, increase the social effect, attract and retain highly qualified personnel, qualitatively upgrade production facilities and create new markets, there is a demand for "greening" modern socio-economic relations. These trends create the basis for formation of the environmental concept at the national and regional levels. Therefore, the question of substantiation of the essence, problems and prospects of regional environmental systems in Ukraine requires further research and qualitative assessment of the results of relevant activities. The concept of environmental economy is developed that actualizes theoretical research and applied analysis of the main aspects of its implementation in the context of the development of innovative regional economy nowadays.

In light of recent trends of sustainable development, it is rather difficult to find studies that provide a comparative analysis of indicators of both innovative and environmental capacity, concerning potential for further innovative and environmental development at the regional level. Thus, the current study tends to highlight the tendencies of regional environmental systems development in Ukraine, namely their innovative capacity and potential of environmental responsibility. The genesis of this thesis can be traced back to the time the authors became interested in sustainable development of innovative regions.

\subsection{Previous researches}

Several previous studies and international organizations reports have found that 
implementation of innovative development and environmental support concepts at the regional level have a significant potential worldwide.

The topic of environmental economy and its manifestation at the regional level provides the basis for appropriate researches' strengthening, including these in works of I. Riepina, R. Constance, V. Bakirov, F. Battel, O. Klimenko, V. Oltra, R. Dunlepa, G. Daly, D. Farley and others. In particular, R. Dunlep, W. Ketton and A. Schneiberg paid attention to the vector of innovative post-industrial society development, which is mostly aimed at the destruction of the natural environment, concerning the urgent need to influence such process globally (Dunlap and Catton 1994). The distinction between economic and non-economic values is reflected in the works of G. Daley and D. Farley, which created a scientific basis for further formation and development of the concept of environmental economy (Daly and Farley 2010). F. Battel was focused on the fact that the social systems have both critical material and environmental ranges of measurement (Battel 1996).

The increase of interest in the concept of regional innovation systems has been driven by the growing intensity of global competition. The traditional local models and policies within the area of environmental support are not sufficient enough to boost innovative development both on the regional and national levels. There is a need of environmentally responsible industries and NGOs (Enright 2001).

The importance of innovation capability and competitiveness of business and particular regions is highlighted within a measure of researches, conducted by (Asheim et al. 2003, Wolfe 2003). Thus, it is argued that firm-specific competencies and learning processes can lead to regional competitive advantages if they are based on localized capabilities such as specialized resources, skills, institutions and share of common social and cultural values. In other words, regional development ensues as competitiveness occurs in places where localized capabilities such as institutional endowment, built structures, knowledge and skills exist. The literature on regional innovation systems has provided substantial description and analysis of relationships between innovation, learning and economic performance of particular regions (Maskell and Malmberg 1999).

Ukrainian scientists determined the theoretical and applied researches on environmental economy influence at business development. An author considered the environmental system dynamics and natural resources limits within the paradigm of environmental friendly and innovative national economy, region and legal entities (Riepina 2015).

The above-mentioned researches mostly consider the nature of the environmental economy and its influence on innovative society. However, there is still a rather little published researches on potential to combine the innovative development and sustainable environment strategies at the regional level. Thus, the chosen problem is of a significant scientific interest nowadays.

\subsection{The scientific problem}

The scientific problem of this article lays upon the potential of regional environmental systems as a driver of innovative economy development in Ukraine. The hypothesis of the paper has both theoretical and applied background, concerning environmental strategies development and their influence on innovative development at regional level. This aims to activate sustainable development both at regional and national 
level. The aim of the current study is to identify the regional dimension of building an environmental economy and its innovative development. The aim is specified in the form of tasks, including the theoretical foundations of the environmental concept of innovative national economy and innovative development at regional level, assessment of existing experience and opportunities for further implementation of environmental ideas in the context of innovative national and regional systems development in Ukraine. The object of the research is the environmental economy boost within regions in Ukraine that provide basis for innovative development. The subject is regional potential of environmental responsibility, contributing the social and economic growth of national economy and its global competitiveness.

\subsection{The research methodology}

The research methodology is based on foreign and Ukrainian scientific literature and statistical data analysis (within the last ten years) to show a link between environmental system and innovative development at the regional level. The primary data of international and Ukrainian environmental and innovative development reports within the last five years are reproduced to confirm appropriate social and economic trends. Particularly, the environmental economy trends are provided, using the methods of economic and mathematic modelling and dynamics. A combination of quantitative and qualitative approaches was used in the innovative development analysis. This provides robust evidence for consideration of regional environmental systems as a driver of innovative economy in Ukraine.

The scientific novelty of the methodology is as follows: in the study, both the innovative development indicators and indicators of environmental influence at the regional level through compartment of their potential. On the one hand, this provides opportunity to define the role of environmental policy for innovative development at the regional level. On the other hand, this allows to estimate the suitability of innovative regions.

\subsection{The current research structure}

The current research consists of the following parts:

- primarily, the theoretical and applied framework based on environmental economy concept and its innovative background is considered;

- then, the phenomenon of environmental systems in Ukraine development, including regional and sectoral structure analysis;

- finally, the research conclusions on environmental responsible model of innovative development on the regional level are provided.

The research practical implication is that results can be used within regional environmental strategies and innovative development models to accept social and economic challenges both on national and regional levels.

\section{Main Theoretical and Applied Assumptions of the Research}

\subsection{Innovative concepts of environmental economy development: manifestation at the regional level}

The environmental economy concept has emerged largely as a result of a 
combination of several branches of research. In particular, an important background for environmental economy development has appeared in late $1970^{\text {th }}$ as the combination sociological and environmental theories (Burch 1979). Questions have been raised about the safety of the prolonged use of natural resources. Thereby, the new actual environmental concept was formed in the mid-1980 th in the USA as a result of intensification caused by negative environmental changes, economic processes and social movements. At the same time, the Brundtland Commission, officially the World Commission on Environment and Development (WCED), was managed within the UNDP in 1983. This determined the development of global environment protection paradigm and appropriate priorities within global strategies of economic and social development with their further widespread at national and regional levels.

Thus, environmental problems have started to be considered within national and regional strategies due to the social and local movements. In particular, there is an increase in demand for innovative products that represents one of the components of accelerating the transition to post-industrial society.

The development of post-industrial society is based on knowledge that are considered as highly effective factor for innovative development. Knowledge are able to transform the traditional factors of production into more sustainable ones, transforming them and significantly increasing the efficiency of their influence (Chuchno 2012). However, nowadays, the knowledge widespread also causes the increase of social demand into environmental responsible activity. In particular, consideration of the relationship between the structural components of innovation economy and the environmental strategies creates the framework of sustainable development at the regional level (Figure 1).

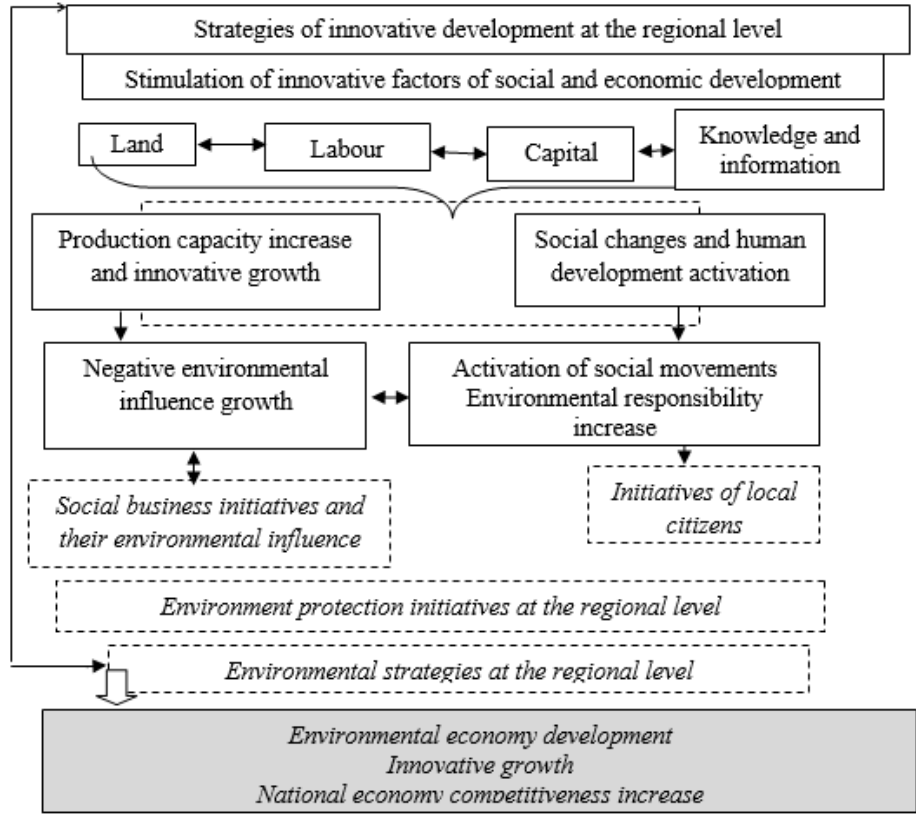

Figure 1: The environmental concept of an innovative economy: causal relationships at the regional level Source: compared by author based on (Chuchno 2012, Sustainability and Equity: A Better Future for All 2020) 
In accordance with actualization of the theoretical and applied aspect of the environmental concept formation, the emphasis is paid on the relationship between the environmental system and further innovative development. Thereby, it is rather important to concern and develop the appropriate synergetic models.

\subsection{Synergetic models of regional evironmental systems development and their innovative nature}

The methodology of innovative development researches indicates that the formalized model of integrated assessment of the effectiveness of regional social and economic development is represented as a ratio that takes into account the impact of social, economic and environmental components (Parshyn 2014):

$\mathrm{EEP}_{\mathrm{i}}=\mathrm{T}_{\mathrm{i}} * G R P_{\mathrm{i}} * \mathrm{~K}_{\mathrm{i}}$,

where EER $i$ is an integral indicator of social and economic development efficiency within the $i$-th region;

$T Z i$ - life expectancy within the $i$-th region, years;

$G R P i$ - gross regional product, thousand UAH;

$K i$ is an integral coefficient of social and economic development efficiency within the $i$-th region, taking into account economic, social and environmental components.

Thus, the potential of sustainable development at the regional level depends on a wide range of indicators. This indicates the effectiveness of the implementation of a number of measures for its optimization within social, economic and environmental components that influence innovative development (Parshyn 2014).

In the context of building an innovative economy in Ukraine, we agree with the expediency of applying the methodology outlined above at the regional level. The regional level is more "local". Thereby, this allows us to pay special attention to exclusively regional priorities and differences. However, in the context of a comprehensive study of the innovative economy there is an interaction between the relevant components of the development of individual regions, a synergistic (cumulative) effect is formed, and some "barriers" (negative effects) are also summed up:

$\mathrm{EEP}_{\mathrm{i} n n o v_{\text {econ }}}=\mathrm{EEP}_{\mathrm{i} 1}+\mathrm{EEP}_{\mathrm{i} 2}+\cdots+\mathrm{EEP}_{\mathrm{i} n}+\mathrm{EEP}_{\mathrm{i} 1}\left(\mathrm{EEP}_{\mathrm{i} 2} \ldots \mathrm{EEP}_{\mathrm{i} n}\right)+\cdots+$ $\operatorname{EEP}_{\mathrm{i} n}\left(\mathrm{EEP}_{\mathrm{i} 1} \ldots \mathrm{EEP}_{\mathrm{i} n-1}\right)$,

where EEPinnov_econ is an integrated indicator of the efficiency of economic development of the innovative economy;

$\operatorname{EEP}_{\mathrm{i} n}\left(\mathrm{EEP}_{\mathrm{i} 1} \ldots \mathrm{EEP}_{\mathrm{in}-1}\right)$ - synergistic (cumulative) effect and "barriers" (negative effects) that arise due to the interaction between the relevant components of the particular regions development.

Thus, the innovative economy formation is deeply connected with increased production through quality improvement. On the one hand, this causes increased negative environmental impacts. However, on the other hand, the growing competitiveness of innovative and active businesses causes the environmental responsibility growth. At the same time, we observe changes in public opinion, considering environmental movement foundation. As the result, national innovative system is formed as the result of innovative and environmental responsible development at the regional level. 


\section{Research Results}

\subsection{Innovativeness and environmental responsibility within Ukrainian economy}

Currently, only a small share of Ukrainian business entities can be considered as innovative. According to the State Statistics Service of Ukraine, in 2013 only $13.6 \%$ of enterprises implemented innovations, in $2014-12.1 \%$, in $2015-15.2 \%$, in $2016-18.9 \%$, in 2017 - 16.2\%, in 2018 - 16.4\%, in 2019 - 16\% (Figure 3). However, in the countries of the European Union the innovation component is $60 \%$, in South Korea and Japan - 67\%, in the USA - 78\% (State Statistics Service of Ukraine 2020).

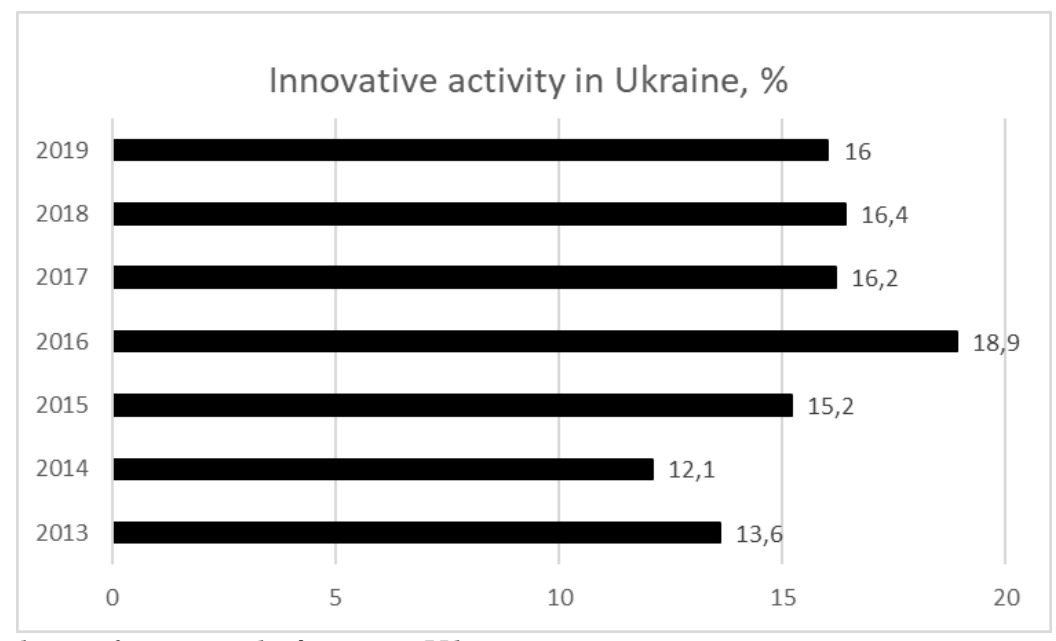

Fig. 3. Tendencies of innovative development in Ukraine

Source: compared by authors on the basis of (State Statistics Service of Ukraine 2020)

The main shares of innovative active entities are concentrated in Kharkiv region and Kyiv, making $14 \%$ and $10 \%$ respectively. The level of innovative activity higher than the average in Ukraine is typical for Volyn, Vinnytsia, Khmelnytsky, Chernivtsi, Lviv regions. At the same time, the largest share of current expenditures on the protection and rational use of natural resources falls on the Dnieper region (32\%), Kyiv accounts for 9\%, Kharkiv region - 5\% (State Statistics Service of Ukraine 2020).

At the same time, the implementation of the environmental concept is mainly based on the tools of environmental marketing. In particular, one of the components of McDonald's success within the national market is not only the renewal of the range of products and production technologies, but also charity events and sponsorship of important socially significant projects. In our opinion, one of the aspects of intensifying the participation of business entities in the formation of the environmental concept and strengthening innovation activity is their promotion and comprehensive support, which is possible by attracting resources at the national and regional levels.

Recently, the amount of funding for the strategic priority "Development of new technologies for energy transportation, introduction of energy-efficient, resource-saving technologies, development of alternative energy sources" increased slightly compared to previous periods (Analytical reference 2018) (Figure 4). 


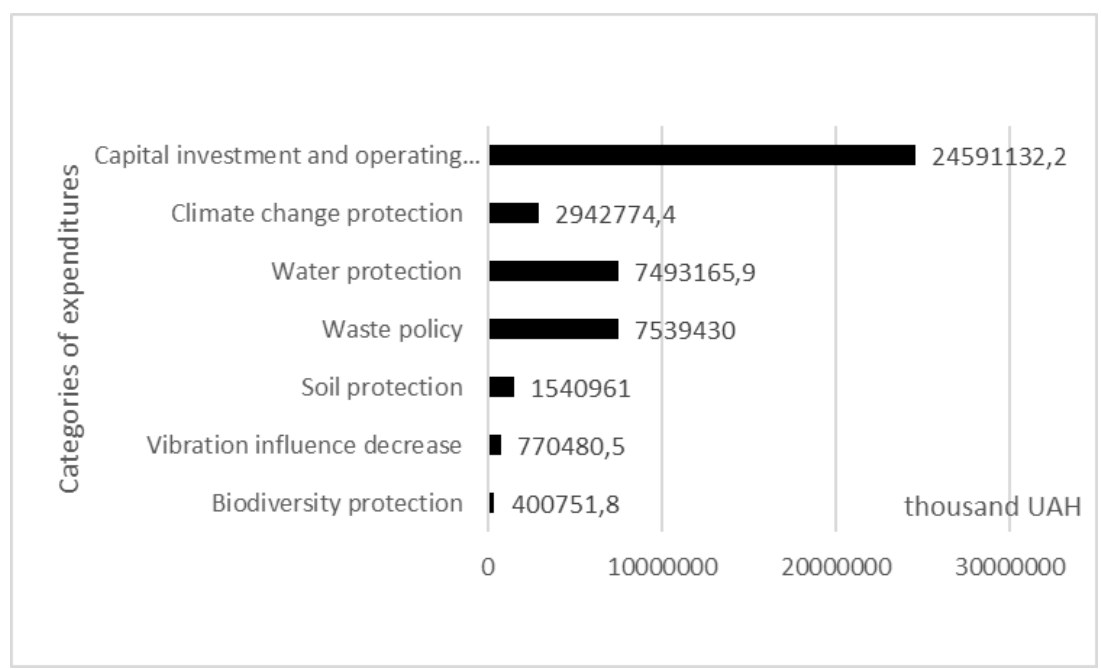

Fig. 4. Environmental expenses for innovative development in Ukraine

Source: compared by authors on the basis of (State Statistics Service of Ukraine 2020)]

However, an important basis of the potential of the environmental component of the innovative economy is the stimulation of specific areas of environmental activities of innovative enterprises at the regional level. This will allow us to focus on issues that are key to sustainable innovation development both at the regional and national level.

\subsection{Innovative development and environmental priorities of Ukrainian regions}

The increased attention on synergetic models of regional environmental systems development and their innovative nature causes the need to develop appropriate general analytical approaches for their practical implication. For instance, one among such analytical approaches pays attention to the subject in accordance with their readiness and ability to simultaneously carry out innovative activities and implement environmental priorities, namely:

- strategic eco-innovators, who consider the basis of their main activity to be environmental innovations, eco-equipment use;

- strategic eco-adapters that adapt or improve the eco-innovation of other subjects, but the main component of their activity is not the production of innovations to preserve the environment;

- passive eco-innovators, who do not develop a specific eco-strategy, but organize the process of production of innovative products with the least possible negative impacts on the environment, provide periodic eco-benefits;

- non-environmental innovators who do not implement any innovative activities with ecobenefits for society (Kemp 2007).

The above-mentioned methodology is used to conduct detailed distribution and ranking of costs for protection and rational use of natural resources by region in Ukraine. As a result of the ranking we can conditionally distinguish four groups of regions depending on the degree of development of their environmental systems (Table 1). 
Table 1: Regional environmental systems in the innovative economy of Ukraine

\begin{tabular}{|c|c|c|c|}
\hline Region & Rank & Group & $\begin{array}{l}\text { Requirement for regional } \\
\text { environmental strategies transformation }\end{array}$ \\
\hline \begin{tabular}{|l|} 
Luhansk \\
\end{tabular} & 25 & \multirow{5}{*}{ Critical group } & \multirow{5}{*}{$\begin{array}{l}+ \\
\text { Full review of available strategy, } \\
\text { concerning a plan of action on how to } \\
\text { manage environmental protection. }\end{array}$} \\
\hline Ivano-Frankivsk & 24 & & \\
\hline Zhytomyr & 23 & & \\
\hline Kherson & 22 & & \\
\hline Lviv & 21 & & \\
\hline Kirovograd & 20 & \multirow{6}{*}{ High risk group } & \multirow{6}{*}{$\begin{array}{l}+ \\
\text { The environmental strategy should fully } \\
\text { concern stakeholder pressures and market } \\
\text { opportunities. }\end{array}$} \\
\hline Ternopil & 19 & & \\
\hline Transcarpathian & 18 & & \\
\hline Zaporozhye & 17 & & \\
\hline Donetsk & 16 & & \\
\hline Chernihiv & 15 & & \\
\hline Cherkasy & 14 & \multirow{7}{*}{$\begin{array}{l}\text { Stable environmentalization } \\
\text { group }\end{array}$} & \multirow{7}{*}{$\begin{array}{l}\text { The environmental strategy should } \\
\text { provide more tools to generate } \\
\text { competitive advantages }\end{array}$} \\
\hline Volyn & 13 & & \\
\hline Khmelnytsky & 12 & & \\
\hline Vinnytsia & 11 & & \\
\hline Odessa & 10 & & \\
\hline Rivne & 9 & & \\
\hline Sumy & 8 & & \\
\hline Chernivtsi & 7 & \multirow{7}{*}{$\begin{array}{l}\text { Developed environmental } \\
\text { system }\end{array}$} & \multirow{7}{*}{$\begin{array}{l}- \\
- \\
\text { The environmental strategy should be } \\
\text { concerned within the system with } \\
\text { managerial decisions at the regional level }\end{array}$} \\
\hline Kharkiv & 6 & & \\
\hline Poltava & 5 & & \\
\hline Kyiv & 4 & & \\
\hline Dnepropetrovsk & 3 & & \\
\hline Kyiv & 2 & & \\
\hline Mykolayivska & 1 & & \\
\hline
\end{tabular}

Source: compared by authors

In accordance with the above-identified needs and the outlined effects of regional interactions, there is a risk of negative consequences from regions of different critical groups influences. Therefore, the transformation of regional environmental strategies should take place in a synergetic manner, considering the national, regional levels and business, involved in the implementation of the environmental concept.

\section{Conclusions}

Given all that has been mentioned so far, one may state that regional environmental systems are getting growing importance within sustainable society. The primary analytical research of Ukrainian statistics shows the increasing deepening of innovative development from environmental responsibility at the regional level.

Thus, as a result of our study, we can conclude that it is necessary and possible to spread the environmental concept not only in the context of the formation of an innovative economy, but also at the regional level. After all, the innovative economy is formed as a result of the synergy of the strengths of the regions, the leveling of the main risks of 
regional development.

Using the methodology developed in the study of integrated assessment and applied differentiation of the degree of development of the environmental system of individual regions, we concern the following conclusions:

- environmental component remains an integral component of socio-economic development of today (forms the environmental base), so it is advisable to consider it on a par with economic and social components in the construction of integrated indicators; - the state level of the innovative economy is quite general, so to obtain realistic results of the analysis of specific components, it is advisable to conduct appropriate research at the regional level and, subsequently, to generalize it at the state level as a whole;

- when conducting analytical research and calculation of complex indicators it is quite difficult to take into account all the existing components of the environmental system, so in the previous stages of the study it is advisable to use the tools of ranking and grouping. The development of the environmental concept of the innovative economy is the result of appropriate activity of economic entities that need to stimulate and adjust the innovative areas of their activities in view of regional and national priorities. Therefore, in the context of development of environmental regional systems of innovative economy of Ukraine it is necessary to pay attention to the following recommendations:

- it is expedient to form a single state center for analysis and coordination of regional efforts in the context of the development of environmental systems, which will strengthen the coherence of regional strategies, pay more attention to bottlenecks and opportunities for their leveling;

- to start the practice of exchanging experiences in the form of conferences, symposiums, round tables with representatives of business and public organizations at the regional level, which will allow a deeper assessment of existing problems, find common ways to solve them at the regional level;

- to increase the level of analytical and methodological awareness of regional analysts by forming centralized regional bases and resources that will reflect the achievements of modern science and leading foreign experience in the formation of environmental systems within the innovation economy.

\section{References}

Analytical reference. The state of development of science and technology, the results of scientific, scientific and technical, innovative activities, technology transfer in 2017. (2018). Kyiv: Ministry of Education and Science of Ukraine. Ukrainian Institute of Scientific, Technical and Economic Information.

Asheim, B., Isaksen, A., Nauwelaers, C., Tötdling, F. (2003). Regional innovation policy for smallmedium enterprises. USA: Edward Elgar.

Burch, W. (1979). Human Ecology and Environmental Management. The Environmental Professional, 1: 285 292.

Buttel, F. (1996). Environmental and Resource Sociology: Theoretical Issues and Opportunities for Synthesis. Rural Sociology. 1: 56 - 76.

Chuhno. A. (2012). Modernization of the economy and economic theory. Economy of Ukraine, 10: 24 - 33.

Daly, H., Farley, J. (2010). Ecological Economics: Principles and Applications. Island Press, Second edition.

Dunlap, R., Catton, W. (1994). Struggling with Human Exemptionalism: The Rise, Decline and Revitalization of Environmental Sociology. The American Sociologist, 25: 5 - 30.

Enright, M. (2001). Regional clusters: what we know and what we should know. Paper presented for the Kiel Institute International Workshop, 12-13 November, 2001. 
Kemp, R., Pearson, P. (2007). Final report MEI project about measuring eco-innovation. UM Merit, Maastricht.

Maskell, P., Malmberg, A. (1999). Localized Learning and industrial Competitiveness. Cambridge Journal of Economics, 23: 167 - 189.

Parshyn, I. (2014). Integral assessment of the effectiveness of economic development of the region. Development economics, 1 (69): $27-33$.

Riepina, I. M. (2015). The genesis of business result on the way to the environmental economy. Strategy of economic development of Ukraine, 36: 45 - 51.

Social Infrastructure: A Key Factor In Harnessing Demographic Dividend. (2020). SSRN. Available from http://papers.ssrn.com/sol3/papers.cfm?abstract_id $=3212$

State Statistics Service of Ukraine. (2020). Official site. Statistical information. Science and innovation. Scientific and innovative activity $(1990$ - 2019). Available from http://www.ukrstat.gov.ua/

Sustainability and Equity: A Better Future for All. (2020). Human Development Report. Available from http://hdr.undp.org/en/media/HDR_2011_EN_Complete.pdf.

The Ministry of Economy of Ukraine. (2020). Official site. Available from http://www.me.gov.ua

Wolfe, D. (2003). Clusters Old and New: The Transition to a Knowledge Economy in Canada's Regions. Kingston: Queen's School of Policy Studies. 